\title{
Analysis of Aggregate Gradation to Improve The Characteristics of Geopolymer Based Asphalt Concrete
}

\author{
Akhmad Taufik Aditama $^{1 \mathrm{a}}$, Januarti Jaya Ekaputri ${ }^{1 \mathrm{~b}}$, Ervina Ahyudanari ${ }^{\text {1c }}$
}

\begin{abstract}
The previous study showed that asphalt concrete using filler geopolymer generate a higher value of stability. On the other hand, the value of flow and the porosity of the asphalt concrete were out of the specification range. This study examines the aggregate gradation analysis to improve the characteristics of mixed asphalt concrete geopolymer. The gradation of aggregate is variated into three following the available specification. The range of specification is then separated into three; those are aggregate gradation upper specifications, middle specification, and lower specification. Filler comes from geopolymer paste, composed of fly ash which is mixed with an activator. Activator is an eight molar concentration of $\mathrm{NaOH}$ solution and $\mathrm{Na}_{2} \mathrm{SiO}_{3}$. The weight ratio of $\mathrm{Na}_{2} \mathrm{SiO}_{3}$ over the weight of $\mathrm{NaOH}$ solution was 1.5. Geopolymer paste waited until reached the age of 28 days, then pounded up to meet the required size of the sieve No. 200. The test of mixture characteristics was conducted to see the comparison of performance from different gradations. The test results showed that middle gradation generating characteristics of the mixture, which is higher than upper gradation and lower gradataion.
\end{abstract}

Keywords—Asphalt Concrete, Geopolymer, Aggregate Gradation, Marshall Characteristics

\section{INTRODUCTION}

$\mathrm{S}_{\mathrm{e}}^{\mathrm{te}}$ team Power (PLTU) is a place of producing electrical energy, with the primary fuel is coal. The 50 MWatt power plant requires coal fuel with the amount of 210.1 tons/day and produces solid waste in the form of fly ash up to $17284.65 \mathrm{~kg}$ [1]. These wastes can cause health issues and environmental pollution. It must be minimized by conducting research related to the utilization of the waste.

Davodovits [2] proposed that geopolymer can be formed from the polymerization of alumina silicate mineral and high alkali solution. One of these minerals is fly ash. Fly ash is a toxic material, with the polymerization process in this geopolymer, a dangerous mix on the fly ash can be controlled. Ekaputri [3] showed that with the process of geopolymerization, fly ash would form a kind of barrier to trap boron on the fly ash. Therefore, geopolymer more environmentally friendly. Boron is an element on the fly ash, which can pose harm to humans and plants if the concentration is high enough [4].

The use of geopolymer materials has several advantages. Some of them are hard, weather resistant, chemical attack, and high temperatures [5]. Geopolymer also can be used as a substitution of cement; therefore, using geopolymer is considered as an environmental conservation. In the process of cement production, $\mathrm{CO} 2$ emissions were released into the air. The amount of $\mathrm{CO} 2$ equals the production of cement [6]. Other benefits of geopolymer material are its ability to absorb harmful gases from vehicles. Adsorbent made of fly ash can reduce levels of $\mathrm{CO}$ and $\mathrm{CO}_{2}$ emissions of motor vehicles with a maximum contact time of the adsorbent for $\mathrm{CO}$ gas is 12 minutes and for $\mathrm{CO}_{2}$ gas is 14 minutes [7]. The use of nano zeolite-geopolymer as adsorbant managed to absorb $\mathrm{Pb}_{3} \mathrm{O}_{4}$ and $\mathrm{MnO}$ on motor vehicle exhaust gas, which is harmful oxide if inhaled by a human [8].
Geopolymer is a synthesis of alumina silicate (fly ash) and lye (activator). To achieve the desired result, the proportion of both materials should be calculated. Activators that are generally used is a mixture of $\mathrm{Na}_{2} \mathrm{SiO}_{3}$ and $\mathrm{NaOH}$ with concentration $8 \mathrm{M}$ to $14 \mathrm{M}$. The ratio between $\mathrm{Na}_{2} \mathrm{SiO}_{3}$ and $\mathrm{NaOH}$ could be selected in the range of 0.4 to 2.5 [9]. The higher the weight ratio of $\mathrm{Na}_{2} \mathrm{SiO}_{3}$ and $\mathrm{NaOH}$ solution does not guarantee to lead to higher tension stress and compression strength. However, the higher molarity is used, the higher the tension stress and its compressive strength[10].

Fly ash is used as geopolymer filler on the mixture of asphalt concrete. There was a study that was using filler geopolymer in asphalt mixture, which produced high stability than ordinary asphalt mixture [11]. Subsequent research [12] showed that the mix of asphalt concrete using filler geopolymer generate better stability than not using filler geopolymer. However, the use of filler geopolymer produced void in the mixture and the void filled with asphalt is less than the specified value.

To provide an alternatives improvement on the void in the mixture, there is a need to do some research regarding the analysis of aggregate gradation in the mixture of asphalt concrete geopolymer. The aggregate gradation effects on void volume, which is formed in the mixture. The gradation also affects to workability and stability of the mixture. The changes of aggregate gradation treatment on asphalt concrete mixture affect to characteristics of asphalt concrete mixture [13]. Reducing the percentage of porosity by changing the gradation may increase flexibility and reduce deformation. On the other hand, changing gradation can decrease compressive strength [14].

This study attempts to get a variation on the coarse aggregate gradation. It is expected to provide the best performance on the mixture of asphalt concrete incorporating geopolymer. The second objective of this research is to reduce the waste of coal combustion in order

\footnotetext{
${ }^{1}$ Department of Civil Engineering, Institut Teknologi Sepuluh Nopember, Surabaya 60111, Indonesia

an E-mail: aditamataufik0@gmail.com

bE-mail: januartije@gmail.com

'E-mail: ervina@ce.its.ac.id (corresponding author)
} 


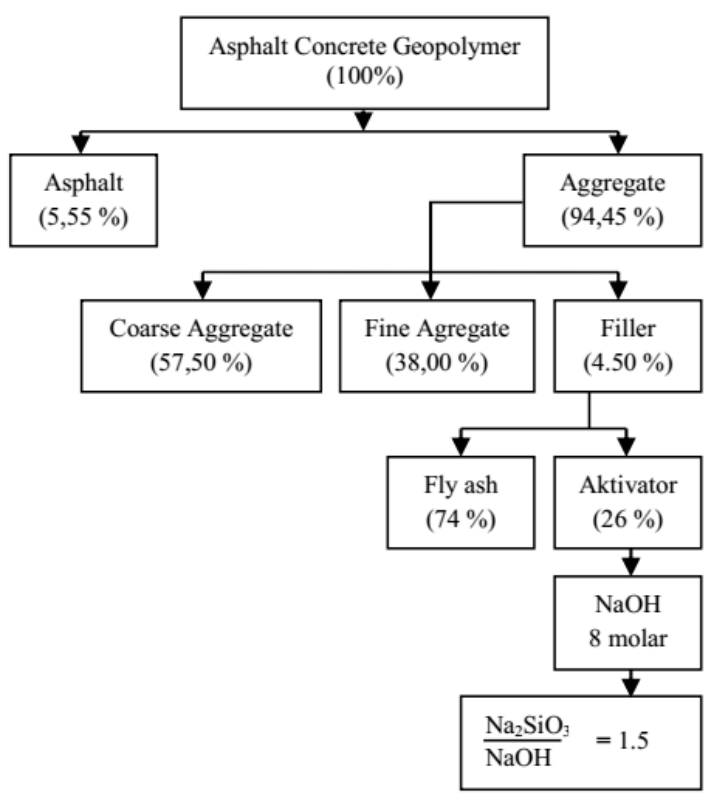

Figure 1. Asphalt Mix Concrete Using Geopolymer Filler

to decrease the effect of the waste on the health and environment.

This study is limited to the following: using penetration 60/70 bitumen produced by PT. Pertamina. Filler geopolymer used is composed of fly ash obtained from Paiton Unit 5 and 6. Paiton is a power plant located in Pasuruan, East Java, Indonesia. Activators are formed from 8 molar concentration of $\mathrm{NaOH}$ solution and $\mathrm{Na}_{2} \mathrm{SiO}_{3}$ [12]. By a weight ratio of $\mathrm{Na}_{2} \mathrm{SiO}_{3}$ to weight $\mathrm{NaOH}$ solution is 1.5.

\section{RESEARCH METHODOLOGY}

Specimens made is a mixture of asphalt concrete. It has a cylindrical shape with a diameter $10 \mathrm{~cm}$ and height \pm 6.5 $\mathrm{cm}$. The mixture of asphalt concrete material consists of coarse aggregate - fine aggregates - filler - asphalt. Then the mixture was molded and crushed $2 \times 75$ times in the tube-shaped mold, after which it is removed and tested characteristics.

Based on mixtures, there are four kinds of asphalt concrete made. It is a mixture of asphalt concrete using filler geopolymer on upper gradation, middle gradation, and lower gradation. And mixtures of asphalt concrete without filler geopolymer (fly ash) in the middle gradation. Overall, the stages of the research conducted are described in more detail as follows:

\section{A. Material Testing}

The material used in the form of aggregates and asphalt. Aggregate testing includes density and absorption, analysis of the sieve, attachment aggregate to asphalt, material sieve no. 200, as well as flakiness and ovality. The tests for asphalt include density, penetration, ductility, flash point, softening point, and viscosity. The tests for material follows Indonesian National Standard (SNI).

\section{B. Filler Geopolymer}

The finer fly ash in the geopolymerization process provides strength, best flow, and drying shrinkage. The mix also reduces time in the formation of geopolymer
TABLE 1. SPECIFICATION OF AGGREGATE GRADATION

\begin{tabular}{cc}
\hline Sieve size $(\mathrm{mm})$ & Public Work V Limits \\
\hline $1 "$ " $(25.4)$ & 100 \\
$3 / 4 "(19,1)$ & $80-100$ \\
$1 / 2 "(12,7)$ & - \\
$3 / 8 "(9,25)$ & $60-80$ \\
No. $4(4,76)$ & $48-65$ \\
No.8 $(2,38)$ & $35-50$ \\
No.30 $(0,59)$ & $19-30$ \\
No. 50 $(0,27)$ & $13-23$ \\
No.100 $(0,149)$ & $14-15$ \\
No. $200(0.074)$ & $1-8$ \\
\hline
\end{tabular}

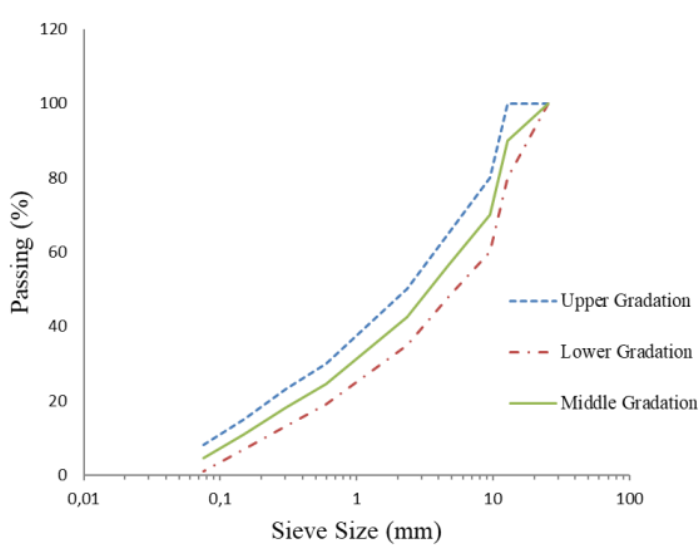

Figure 1. Specification of Aggregate Gradation

[15]. Geopolymer used is composed of fly ash mixed with alkali activator. The activator is a solution of $\mathrm{NaOH}$ and $\mathrm{Na}_{2} \mathrm{SiO}_{3}$ with eight molar concentrations. The weight ratio of $\mathrm{Na}_{2} \mathrm{SiO}_{3}$ to the weight of $\mathrm{NaOH}$ solution is 1.5. Filler geopolymer obtained by mixing fly ash + activator and then allowed to stand for 28 days. The paste of geopolymer is then pounded until pass the sieve No. 200. The proportion of appropriate activators are needed to make good geopolymer. Geopolymer compositions are shown in Figure 1.

\section{Determination of Aggregate Gradation}

Aggregate gradation used was a specification of the upper, middle, and lower of the mixture no. $\mathrm{V}$ based on the common specifications of Bina Marga. Table 1 and Figure 2 show the specifications of aggregate gradation.

\section{Determination of Optimum Bitumen Content}

Optimum bitumen content (OBC) should be estimated for each type of gradation. The estimated bitumen content for each gradation is calculated by the average of [16]

$$
P b=0.035(\% C A)+0.045(\% F A)+0.18(\text { Filler })+K
$$

Where $\mathrm{Pb}$ is ideal bitumen content $(\%), \mathrm{CA}$ is aggregate held by sieve No.8 (\%), FA is aggregate sieve No. 8 and held by sieve No. $200(\%)$, Filler is the aggregate of at least $75 \%$ passes No. 200 , and $\mathrm{K}$ is constant $(0.5 \%-1.0 \%)$

From equation (1), the obtained bitumen contents for upper, middle, and lower gradation are $5.80 \%, 5.30 \%$, and $4.75 \%$ respectively. These asphalt contents are used as the base in preparing a sample of mixed asphalt concrete. Each gradation consists of five variations on asphalt 
TABle 2 Test Result of Characteristics Asphalt Concrete

\begin{tabular}{|c|c|c|c|c|c|c|}
\hline \multirow[t]{2}{*}{ No } & \multirow{2}{*}{$\begin{array}{l}\text { Characteristics of } \\
\text { Asphalt Concrete }\end{array}$} & \multicolumn{3}{|c|}{ Variation of Aggregate Gradation (Geopolymer) } & \multirow{2}{*}{$\begin{array}{l}\text { Middle Gradation } \\
\text { (No Geopolymer) }\end{array}$} & \multirow[t]{2}{*}{ Specification } \\
\hline & & Upper & Middle & Lower & & \\
\hline 1 & $\begin{array}{l}\text { Optimum Bitumen } \\
\text { Content }(\%)\end{array}$ & 6,8 & 5,55 & 5,75 & 5,55 & \\
\hline 2 & Stability $(\mathrm{kg})$ & 2270 & 2408 & 2391 & 2016 & Min 800 \\
\hline 3 & Flow $(\mathrm{mm})$ & 4,70 & 3,82 & 3,30 & 3,93 & Min 3 \\
\hline 4 & $\begin{array}{l}\text { Marshal Quotient } \\
(\mathrm{kg} / \mathrm{mm})\end{array}$ & 523 & 647 & 725 & 513 & Min 250 \\
\hline 5 & VIM $(\%)$ & 3,52 & 4,32 & 4,96 & 4,07 & $\begin{array}{l}\operatorname{Min} 3,5 \\
\operatorname{Max} 5,0\end{array}$ \\
\hline 6 & VMA $(\%)$ & 19 & 17 & 18 & 17 & Min 15 \\
\hline 7 & $\operatorname{VFA}(\%)$ & 81 & 75 & 72 & 76 & Min 65 \\
\hline 8 & Density $\left(\mathrm{gr} / \mathrm{cm}^{3}\right)$ & 2,37 & 2,40 & 2,40 & 2,41 & \\
\hline
\end{tabular}

content. These variations are obtained by adding the asphalt content in the range of $\pm 0.5 \%$ to $\pm 1 \%$. There are two samples prepared for each level of bitumen content. Therefore, the total of samples is 30 pieces. The results of mixture testing meet the specifications of asphalt concrete are $6.80 \%, 5.55 \%$, and $5.75 \%$ for upper, middle, and lower gradation.

\section{E. Making Mixed Asphalt Concrete}

Asphalt concrete mixture is designed in four types. Three of it using ing of the specimen in the air, water, and saturated or dry surfaces. The testing using a marshall generate value stability and flow while weighing the specimen to determine the volumetric properties of the mixture. This test is based on SNI 06-2489-1991 [17].

\section{RESULTS AND DISCUSSION}

Based on the results of laboratory tests, the characteristics of mixed asphalt concrete geopolymer is shown in Table 2.

Table 2 shows that there are four compositions of mixtures. Three mixes using geopolymer filler for upper, middle, and lower gradation. One mixture is middle gradation without geopolymer filler. The tests of mixture characteristics are based on General Specifications Highways. The test results showed that all the mixtures have the characteristic value meets the specification. To find out more detail about the effects of using geopolymer filler and variation on aggregate gradation on each characteristic of mixed asphalt concrete can be explained in the following description:

\section{A. The Effect of Aggregate Gradation on Optimum Bitumen Content}

Table 2 shows that the optimum bitumen content on upper gradation is $6,80 \%$. This is larger than the middle gradation and lower gradation at $5.55 \%$ and $5.75 \%$ respectively. This may occur due to the content of the upper aggregate gradation, which has filler more, and the aggregate size is finer than middle gradation and lower gradation. The optimum bitumen content for lower gradation larger than middle gradation due to the aggregate size of lower gradation is rougher, therefore, requires more asphalt to fill the voids in the mixture.

\section{B. The Effect of Aggregate Gradation on The Stability}

The stability on upper gradation, middle gradation, and lower gradation are $2269.67 \mathrm{~kg}, 2407.77 \mathrm{~kg}$, and 2390.68 $\mathrm{kg}$ respectively. The more coarse gradation, the higher the stability value resulted. The middle gradation results in higher stability since the middle gradation has a balance aggregate size, minimum porosity, high density, and the least asphalt used. In contrast with upper gradation, even though it has a minimum porosity but the aggregate tends to be smooth, so it is resulting in a lack of internal friction arising from aggregate surface roughness and abilities in interlocking between the grains. Likewise with lower gradation, although the aggregates tend to be rough and can produce friction, large enough porosity is formed, consequently can affect interlocking and resulted in stability.

In another study [18], with the increase of coarse aggregate, the strength and stability at high temperatures will decrease. It can happen because the aggregate used is an open-graded. An open-graded aggregate is a distribution of grains which the pores are not well filled [19]. The high stability showed the ability to receive the load without changing the form of getting better.

\section{The Effect of Aggregate Gradation on Flow}

The flow on the upper gradation is $4.70 \mathrm{~mm}$, higher than the middle gradation and the lower gradation, which is $3.83 \mathrm{~mm}$ and $3.30 \mathrm{~mm}$, respectively. The more upper graded mixture, the higher flow resulted. The content of fine aggregate, which increasingly leads to higher flow value and reduced levels of fine aggregate, will reduce the value of flow [20]. The higher the flow, the more pliable and flexible the mixture. The more pliable signifies that the mixture is able to adapt due to a drop without cracking. Such conditions can be achieved by using a high bitumen content and finer mixture. However, the use of bitumen that is too high is also not good for mixed properties. The more asphalt will cause the blanket of asphalt on the aggregate grew thicker, so it causes bleeding and increasingly slippery roads [19].

\section{The Effect of Aggregate Gradation on Marshall Quotient}

The Marshall Quotient for the lower gradation is 724.45 $\mathrm{kg} / \mathrm{mm}$. This is larger than the middle gradation $(647.21$ $\mathrm{kg} / \mathrm{mm})$ and upper gradation $(522.83 \mathrm{~kg} / \mathrm{mm})$. The Marshall Quotient is a quotient of stability value and flow, so to achieve that large Marshall Quotient required high stability and low flow and vice versa. The large Marshall 
Quotient shows the mixture is more rigid and not easily deformed. It is different from gradation on it, which has lower stability and larger flow. It illustrates that the mixture is not that rigid and more easily deformed. Besides, the large Marshall Quotient shows that the mixture is more resistant to shear or abrasive. This roughness is aimed to provide frictional forces on the wheels of the vehicle, especially in wet conditions.

\section{E The Effect of Aggregate Gradation on The Void in Mixture}

The Void in Mixture upper gradation is $3.52 \%$, smaller than the middle gradation that is $4.32 \%$ and lowers gradation at $4.96 \%$. This occurs because the upper gradation has a mixture which is finer and more content of filler, so can minimize the cavity formed. Where as lower gradations the mixture tends to be rough and less content of filler, consequently leaving a large cavity. It is also shown in other studies; a rough mixed had more air cavities and porous, the porous mixed, resulting increase of permeability to water [21]. Increasing permeability of water can accelerate the asphalt surface to oxidizes; the mixture becomes brittle, thereby decreasing durability. The amount of pore showed the durability of asphalt concrete in restraining the burden of traffic, the friction of wheel, and the wear caused by weather and climate. Beside the pores in the mixture, asphalt content can also affect the durability. The thicker the blanket of asphalt, asphalt concrete more waterproof, so it is excellent in restraining wear. The blanket of bitumen, which is too thick, can cause bleeding and slippery. However the existence of voids in the mixture is also needed, its function to a shift in aggregate grains due to traffic loads or point asphalt softened when high temperatures.

\section{F. The Effect of Aggregate Gradation on The Void in The Mineral Aggregate}

The Void in the mineral aggregate upper gradation is $18.92 \%$, higher than the middle gradation that is $17.04 \%$ and the lower gradation at $18.07 \%$. In line with that results, other studies indicate that the voids in the mineral aggregate may increase as the rising the percentage of fine aggregate in the mixture [22]. In particular, bitumen content voids in the mineral aggregate is able to reach its optimum point, then will increase as the rising of asphalt content. Voids in the mineral aggregate will increase if the blanket of asphalt is thicker, or aggregate used is an open graded aggregate [19]. Voids in the mineral aggregate also play a role in determining the durability of asphalt concrete. The smaller voids in the mineral aggregate, the higher level of durability. The middle gradation has the lowest void in the mineral aggregate because the asphalt level used less than the upper and the lower gradation. This can occur due to the mixture of middle gradation has fine and coarse aggregates are balanced. So the aggregate complementary fills the voids and minimize the use of asphalt

\section{G. The Effect of Aggregate Gradation on The Void Filled Asphalt}

The volume of voids filled with asphalt upper gradation is $81.38 \%$, larger than the middle gradation, that is $74.66 \%$ and the lower gradation at $72.53 \%$. This occurs because the use of asphalt on upper gradation is higher than the middle and the lower gradation. The volume of voids filled with asphalt in the mixture is affected by its asphalt concentration, the more use of asphalt so that it can increase the volume of voids filled with asphalt [23]. The middle gradation has a volume of voids filled with asphalt is larger than the lower gradation, whereas the asphalt content is low. This may happen because the lower gradation has the mixture tends to coarse, which can absorb the bitumen into the material, so that the volume of voids filled with asphalt being small. The volume of voids filled with asphalt will be more increase in line with the increasing number of fine aggregate [24]. The increasing volume of voids filled with asphalt reduces void in the mixture. Voids in the mixture are inversely proportional to the value of the volume of voids filled with asphalt.

\section{H. The Effect of Aggregate Gradation on Density}

The density in the middle gradation, $2.40 \mathrm{~g} / \mathrm{cm}^{3}$, which is higher than the upper and the lower gradation, ie 2.38 $\mathrm{g} / \mathrm{cm}^{3}$. A similar incident was stated [25] the largest density obtained on middle range gradation. This can happen because the middle gradation has coarse aggregate, fine aggregate, and fillers are balanced. The higher density shows the mixture more tight and solid. When the mixture is getting solid, the stability will increase, the cavity formed slightly and minimized the using of asphalt. The upper gradation has a density that tends to smaller than the middle gradation, while the upper gradation has a minimum air cavity. This may occur because the upper gradation contains aggregate which tends to smooth and asphalt use is high, so when weighed in the water it has lighter weight, consequently reduce the weight of its contents

\section{Effect of Filler Geopolymer on Characteristics} Asphalt Concrete

Based on table 2 know that the middle gradation made with two mixtures, i.e., the mixture using filler geopolymer and without geopolymer. The test results of characteristics show that stability using filler geopolymer $2407.77 \mathrm{~kg}$ larger than without filler geopolymer (fly ash) $2016.49 \mathrm{~kg}$. This happens because the filler geopolymer contains sodium silicate, which has fused with fly ash. The contain of sodium silicate on geopolymer paste mixture, can enhance compressive strength [26].

For the void in mixture and voids in the mineral aggregate produced using filler geopolymer respectively by $4.32 \%$ and $17.04 \%$, higher than without filler geopolymer $4.07 \%$ and $16.83 \%$. This may occur due to microstructure filler geopolymer shaped irregular and perforated, so it causes many pores are formed. The low Void in mixture and voids in the mineral aggregate made the mixture more durable because the more pores were causing not watertight and the asphalt blanket easily oxidized with air so that it becomes brittle (durability decreases).

As for the other characteristics of different values, but not too significant. The value flow, marshall quotient, void in the mineral aggregate, void filled asphalt and density with filler geopolymer in a row is $3.82 \mathrm{~mm}$; $548.88 \mathrm{~kg} / \mathrm{mm} ; 4.32 \% ; 17.04 \% ; 74.66 \%$ and $2.4 \mathrm{gr} / \mathrm{cm}^{3}$. While the mixture without geopolymer is $3.93 \mathrm{~mm}$; $512.71 \mathrm{~kg} / \mathrm{mm} ; 4.07 \% ; 16.83 \% ; 75.84 \%$ and $2.41 \mathrm{~g} / \mathrm{cm}^{3}$. 


\section{CONCLUSION}

Asphalt concrete has been made using four types of mixture, three mixture use filler geopolymer, namely on upper gradation, middle gradation, and lower gradation. One mixture without filler geopolymer (fly ash), using the middle gradation. From the test results of mixture characteristics, the use of the middle gradation provides better performance than the upper gradation and the lower gradation. The characteristics value of the middle gradation mixture tends to be in the middle of the specification, thus allowing to be applied in the field. As for the upper gradation and the lower gradation produce high flow and low void in the mixture, which is approaching the limits of the specification. Likewise, the lower gradation produces low flow and too large void in the mixture, which approaches the specification limits.

For the using of filler geopolymer in asphalt concrete can increase the value of stability and slightly enlarge the voids mixture. Meanwhile, another characteristic has a different value but not too significant.

\section{REFERENCES}

[1] Megasari, K., Deni S., dan Maria C.P., Penakaran Daur Hidup Pembangkit Listrik Tenaga Uap (PLTU) Batubara Kapasitas 50 MWatt. Seminar Nasional IV SDM Teknologi Nuklir. STTN-Batan Yogyakarta, 2008

[2] Davidovits, J., Geopolymers of the first generation: SILIFACEProcess, "Geopolymer '88, First European Conference on Soft Mineralogy, Compiegne, France, 49-67, 1988.

[3] Ekaputri, Koichi Maekawa, and Tetsuya Ishida, "The Use of Geopolymerization Process for Boron Fixation in Fly ash," Symposium Beton dan Semen Internasional, 2010.

[4] Ekaputri, Januarti J., "Leachable Boron from Fly ash," Jurnal PURIFIKASI, volume 12 no 2 July 2011. ISSN 1411-3465, page 43-52, 2011.

[5] Davidovits, J., "Geopolymer: Inorganic Polymeric New Materials," Geopolymer Institut, 1991.

[6] Davidovits, J., Global Warming Impact on the cement and aggregate industries, World Resource Review, 6, (2), 263-278, 1994.

[7] Faradilla, A.R., Hernani Yulinawati dan Endro Suswantoro, "Pemanfaatan Fly ash Sebagai Adsorbent Karbon Monoksida Dan Karbon Dioksida Pada Emisi Kendaraan Bermotor," Seminar Nasional Cendekiawan, ISSN (E): 2540-7589, ISSN (P): 24608696, 2016

[8] Saludung, A., Nurhatija HS., Sulfiana S., dan Subaer, "Pengembangan Material Nanozeolit-Geopolymer sebagai Adsorbent Gas Buang Kendaraan Bermotor," Prosiding Pertemuan Ilmiah XXIX HFI Jateng \& DIY, Yogyakarta 25 April 2015 ISSN: 0853-0823, 2015.

[9] Hardjito, D., Wallah S.E dan Rangan, B.V, "Factor Influencing The Compressive Strength of Fly ash Based Geopolymer Concrete," Civil Engineering Dimension. 6. Issue: 2, pp 88, 2004.
[10] Ekaputri, J.J. dan Triwulan, "Sodium sebagai Aktivator Fly ash, Trass dan Lumpur Sidoarjo dalam Beton Geopolymer," Jurnal Teknik Sipil, Vol. 20 No 1, 2013.

[11]Muhammad Aiman bin Ismail, "Creep Properties of Geopolymer Bituminous Mixtures," Universiti Teknologi Petronas, 2011.

[12] Ahyudanari, E., Ekaputri, J.J., Tardas, M., "Analysis of Coal Waste Solidification as an Alternative Filler Material in Asphalt Concrete Mixture," Material Science Forum, ISSN: 1662-9752, Vol 841, pp 65-71, DOI: 10.4028/www.scientific.net/MSF. 841.65, 2014.

[13] Ariawan dan Widhiawati, "Pengaruh Gradasi Agregat Terhadap Karakteristrik Campuran Asphalt concrete," Jurnal Ilmiah Teknik Sipil, Volume 14, No.2, 2010.

[14] Golalipour, A., Jamshidi, E., Niazi, Y., Afsharikia, Z., and Khadem, M., "Effect of Aggregate Gradation on Rutting of Asphalt Pavements," Elsevier Ltd. Selection and/or peer-review under responsibility of $\quad$ SIIV2012 Scientific Committee,doi:10.1016/j.sbspro.2012.09.895, 2012.

[15] Chindaprasirt, P., Chareerat, T., Hatanaka, S., Dan Cao, T., 2011, High-Strength Geopolymer Using Fine High-Calcium Fly ash, J Mater. Civ. Eng., 10.1061/ (ASCE)MT.1943-5533.0000161, 264270

[16]Kementerian Pekerjaan Umum, Spesifikasi Umum Perkerasan Aspal, Divisi 6 (Campuran Aspal Panas), 2010, Jakarta.

[17] Standar Nasional Indonesia, SNI, 1991, Metode Pengujian Campuran Aspal Dengan Alat Marshall, SNI-06-2489-1991, Pustran-Balitbang PU

[18]Qi-lin FU and Shuan-fa CHEN, 2010, Influence of Aggregate Gradation on Pavement Performance of Open-graded Large Stone Asphalt Mixes, ICCTP: Integrated Transportation Systems, Green $\cdot$ Intelligent $\bullet$ Reliable CASCE

[19]Sukirman, S., 2003, Beton Aspal Campuran Panas, Bandung, Penerbit Nova.

[20]Korua WJ., Oscar H. Kaseke, dan Lintong Elisabeth, 2015, Pengaruh Jumlah Kandungan Fraksi Bahan Pengisi Terhadap Kriteria Marshall Pada Campuran Beraspal Panas Jenis Lapis Aspal Beton-Lapis Aus Bergradasi Halus, Jurnal Sipil Statik Vol.3 No.12 (847-852) ISSN: 2337-6732

[21]Waddah, SA., Mohammed, TO., Nazem, M., 1998, Influence Of Aggregate Type And Gradation On Voids Of Asphalt Concrete Pavements, Journal Of Materials In Civil Engineering, ASCE, ISSN 0899-1561 / 98 / 0002-0076- Paper No. 13052

[22]Weidong C., Shutang L., Yingyong L., and Zhichao X., 2016, Effect of Aggregate Gradation on Volumetric Parameters and the High Temperature Performance of Asphalt Mixtures, Geo-China, GSP 26642.

[23] Sumiati, dan Sukarman, 2014, Pengaruh Gradasi Agregat Terhadap Nilai Karakteristik Aspal Beton (AC-BC), PILAR Jurnal Teknik Sipil, Volume 10, ISSN: 1907-6975.

[24]Ator PC., Waani, dan Kaseke, 2015, Pengaruh Variasi Kandungan Bahan Pengisi Terhadap Kriteria Marshall Pada Campuran Lapis Aspal Beton-Lapis Antara Bergradasi Halus, Jurnal Sipil Statik Vol.3 (813-820) ISSN: 2337-6732.

[25] Syarwan, Sulaiman, dan Ferry H., 2013, Kajian Gradasi Agregat Beton Aspal Lapis Aus (AC-WC) Terhadap Nilai Parameter Marshall Berdasarkan Spesifikasi Bina Marga Tahun 2010, REINTEK. Vol.8, ISSN 1907-5030

[26]Susanto F., Alvin AW., Antoni, Djwantoro H., 2015, Pembuatan Pasta Ringan Geopolimer Cellular Lightweight Concrete (Clc) Berbasis Campuran Lumpur Sidoarjo Dan Fly ash, Program Studi Teknik Sipil Universitas Kristen Petra. 